\title{
Rapid increase in numbers and change of land-use in two expanding Columbidae species (Columba palumbus and Streptopelia decaocto) in Algeria
}

\author{
Djamel Bendjoudi ${ }^{1}$, Jean-François Voisin ${ }^{2}$, Salaheddine Doumandji ${ }^{3}$, Amel Merabet ${ }^{4}$, Nassima Benyounes ${ }^{4}$ \\ and Haroun Chenchouni $i^{5,6^{*}}$
}

\begin{abstract}
Background: Investigating population ecology of urban bird species, particularly the invasive and expending species, is the key for the success of urban management and planning strategies.

Methods: Populations of two Columbidae species, the Woodpigeon (Columba palumbus) and the Eurasian Collared Dove (Streptopelia decaocto), were monitored from 1992 to 2010 in the Algiers Sahel, the Mitidja Plain and surrounding areas (Northern Algeria). Monitoring of species densities was performed by the mapping-plot method. The foraging flight routes of Woodpigeon and the distribution of Eurasian Collared Dove were assessed by systematic observations.

Results: The number of counted birds was statistically constant at first years of the survey, and then increased significantly, beginning from low numbers, their densities accelerated sharply between 2001 and 2006, then reached to an equilibrium state. The significant increase in Woodpigeon's population could be explained by the reduced hunting pressure and by species adaptation to new food resources provided by nearby agriculture. Indeed, monitoring of flight directions of the species revealed the use of agricultural landscapes and habitats, which is a good indicator explaining adaptation and trophic niche of the species. The occurrence of the Eurasian Collared Dove in Algiers began in 2000. Its density experienced a rapid increase with similar trend pattern as that of Woodpigeon. Its distributional range is confined mainly in suburban environments of the Mitidja Plain.
\end{abstract}

Conclusion: The modifications of habitats, urbanization increase and the lessening of hunting in the Mitidja Plain facilitated the rapid expansion of the Eurasian Collared Dove and Woodpigeon as well contributed to the increase in their numbers over time.

Keywords: Columba palumbus, Flight routes, Mitidja plain, Population dynamics, Streptopelia decaocto

\section{Background}

Ecological monitoring is a core activity for the conservation of biodiversity and conservation biology [1]. Maintaining biodiversity requires a spatial planning for the

\footnotetext{
*Correspondence: chenchouni@gmail.com

${ }^{5}$ Department of Natural and Life Sciences, Faculty of Exact Sciences and Natural and Life Sciences, University of Tebessa, 12002 Tebessa, Algeria

Full list of author information is available at the end of the article
}

conservation of both species and their habitats [2]. Population dynamics refers to the population change over time, and its trend is therefore a crucial component in population ecology. Some bird populations are relatively constant over time, others fluctuate (i.e. their numbers alternate between increase and decrease), while others are continuously increasing or declining. Information on population dynamics are thus essential to determine the status of different populations, which is itself an important management tool [3]. 
Currently, biological invasions are at the heart of many ecological concerns because of their threat to economy, ecosystem integrity and biodiversity. Studies in relation to invasive species problems are numerous (e.g. [4-6]). The International Union for Conservation of Nature (IUCN) considers biological invasions as the second major cause of biodiversity loss worldwide, right after habitat destruction. Naturalized species are considered invasive when they induce significant changes in composition, structure and/or functioning of ecosystems due to their high proliferation in natural or modified environments $[4,7]$.

Birds with high risk of extinction are primarily associated with the threats caused by invasive species. As expected, the negative impact of invasive species was higher on island species due to habitat isolation and species ecological niche specialisation $[8,9]$. Kumschick and Nentwig [10] provided an initial categorization of the impacts of invasive birds in Europe, and argued that several invasive bird species must be eradicated because they seriously threaten biodiversity. Within the absence of competitors and predators, and often under disturbed conditions, invasive species affect ecosystem functioning, causing the disappearance of other species, primarily native and specialist species $[8,10]$.

Many urban and suburban bird studies proved their usefulness in the development and establishment of urban management, biodiversity conservation and planning strategies $[9,11]$. The abundance of birds in urban and suburban environments can reach values higher than in the natural habitats, although the diversity decreases along the gradient of urbanization [12-14]. In most cases, bird populations that cause problems in cities are not there confined at all times; for example, they forage in the nearby countryside, or disperse over other locations [15].

Columbidae species in Algeria are very little studied except certain observations in some localities [3, 16-19], including a comprehensive study of BoukhemzaZemmouri et al. [20] that outlined the breeding ecology of European Turtle Dove in Kabylia and the region of Zeralda, which is located about thirty kilometres from Algiers. Moreover, Bendjoudi [16] and Bendjoudi et al. [3] reported that populations of Columbidae species in Algiers and the Mitidja Plain have increased significantly during last years.

In this study, we will address some ecological aspects associated with the population increase of two Columbidae species: the Woodpigeon and the Eurasian Collared Dove. We particularly want to draw parallels between natural range expansion due to human modification of the environment and biological invasions, which are also strongly linked to anthropogenic influences. In addition to the determination of population trends, the current survey highlights the probable causes that explain these trends. Moreover, the study investigates Woodpigeon's flying routes in order to determine foraging habitat uses, and it monitors spatial occurrences of the Eurasian Collared Dove to assess its distribution patterns and chronological expansion. This study provides important and updated information on population dynamics and patterns of land-use in bird species, which represents a relevant indicator for assessing and understanding environmental change.

\section{Methods}

\section{Study area}

The study area includes two geographic areas: (1) the Algiers Sahel spanning nearly 65,000 ha, with rugged landscapes consisting of cliffs, hills and valleys covered with forests of Aleppo pines and Eucalyptus, private orchards (citrus and Rosaceae trees), and fallowwastelands, and (2) the Mitidja Plain and its surrounding neighbouring occupies nearly 150,000 ha (Fig. 1). Agricultural landscapes mainly covers the Plain, which includes scattered Mediterranean vegetation-types structured as forest stands on the banks of wadis, where the dominant tree species are Populus alba, Fraxinus excelsior, Ulmus minor and Quercus suber. The climate is Mediterranean-type with a long moist and cool period during fall-winter, and a short dry-hot spring-summer period. The rainfall is irregular and varies between 450 and $900 \mathrm{~mm}$ per year.

Around Algiers, landscapes gradually vary from the city to the suburbs and countryside with scattered small forest and plots of vegetable crops surrounded by windbreak of Casuarinas (Casuarina equisetifolia) and Mediterranean Cypress (Cupressus sempervirens). In this region, the park of the National High School of Agronomy-El Harrach (ENSA) is located at $36^{\circ} 43^{\prime} \mathrm{N}, 3^{\circ} 09^{\prime} \mathrm{E}$ in mixed agricultural and suburban area (Fig. 1). The park is a mixture of gardens, lawns, fallow land and tree cultivation areas and vegetable crops, with some educational buildings. The park covers 30 ha, of which only 10 ha were selected for monitoring the variation of specific density of the two Columbidae species. Illegal hunting occurs throughout the region of Algiers, but it is almost non-existent inside the park.

\section{Data collection}

The bird surveys were conducted over 19 years, from 1992 to 2010, in which the mapping-plot method [21, 22] was used to measure densities of breeding pairs of the Woodpigeon and the Eurasian Collared Dove. This method was slightly modified to suit the purpose of our study: at each observation, we walked the retained 10 ha in ENSA Park, at the time of sunrise, and mapped all 


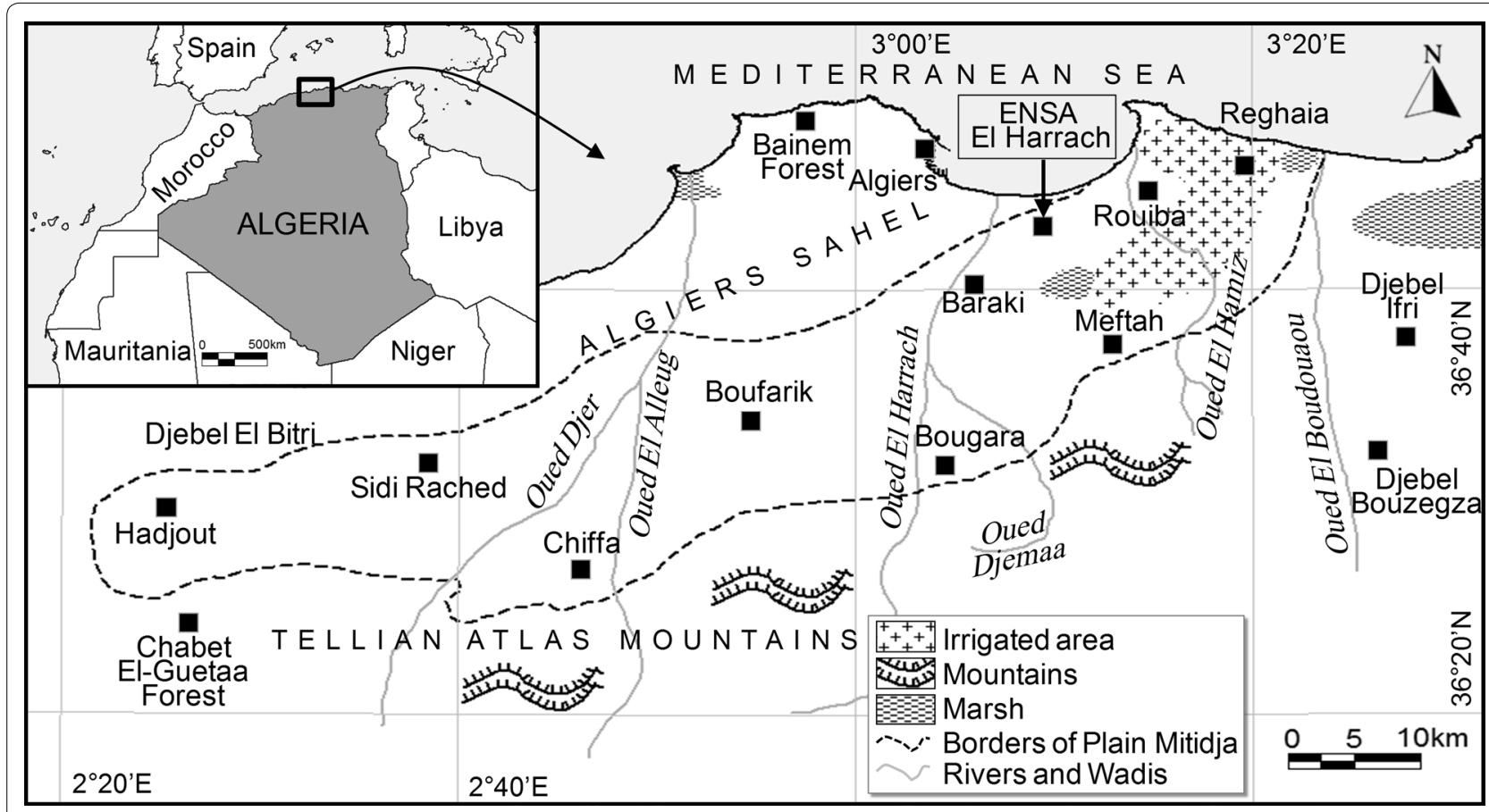

Fig. 1 Location of the study area (Algiers Sahel, Plain of Mitidja and neighbour surroundings). The filled black squares represent the sampled sites

visual and auditory contact of birds, each species with different mark. During the breeding season (FebruaryMay) of each study year, we conducted 16 surveys of 90 min each, with an average of four surveys per month.

In parallel, we carried out systematic observations on the foraging flights of Woodpigeons and the distribution of the Eurasian Collared Dove throughout the study area (Algiers Sahel, Plain of Mitidja and adjacent areas) including both urban and interurban areas. Movement directions of Woodpigeon groups were surveyed between 06:00 AM and 08:00 AM by counting the numbers of individuals according to their flight direction. The surveys were conducted three times per month from March to May 2006. Flight routes of the Woodpigeon were determined from Algiers Sahel (Ben-Aknoun Zoological Park, Garden of Hamma, and ENSA Park) toward some areas in the Mitidja Plain (Oued Smar, Eucalyptus, Meftah, Birtouta, and Boufarik) (Fig. 1), and vice versa. We also investigated nesting and roosting sites in parallel with the monitoring surveys of the Eurasian Collared Dove. Feeding behaviour of the Woodpigeon and the choice of consumed plants were carried out using direct observations throughout the year across habitats of the sites we sampled (Fig. 1). In observations, plant species and parts of these plants being foraged on were recorded for individuals and flocks of the foraging woodpigeons. Furthermore, the Eurasian Collared Dove was surveyed between 2004 and 2008, with a total of 180 surveys at an average rate of three times a month. The collected data were mapped to identify the distributional range of the species based on its location occurrences.

\section{Statistics}

First, values of species densities were plotted against the monitoring years to observe the trend of population dynamics and then choosing the best model that fit that distribution. This procedure helped to decide on the statistical analysis testing for the relationship (linear of nonlinear) between surveyed years and the change in species densities (number of pairs per $10 \mathrm{ha}$ ). As a curvilinearity 'nonlinear relationship' was observed in annual population trends of both surveyed species that have a S-shaped curve, we analysed data using a nonlinear regression model with a four-parameter logistic function that represents one of the $\mathrm{S}$-shaped functions available in the package \{stats\} of R [23]; R Core [24]. We used the 'nls' function, which stands for 'non-linear least squares', to model the dynamic of species densities $(N)$ over surveyed years $(Y r)$. The four-parameter logistic function has asymptotes at the left- $(A)$ and right-hand $(B)$ ends of the $\mathrm{x}$-axis and scales $(C)$ the response to $x$ about the midpoint $(D)$ where the curve has its inflexion, following the formula: $N=A+((B-A) /(1+\exp ((C-Y r / D)))$. Because it is quite challenging to guess the starting parameter values (A, B, C, D) of the model, the self-starting function 'SSfpl' was used for the four-parameter logistic model [25]. 
In addition, two-way ANOVA was carried out to test variation of Woodpigeon individuals between flight directions (eight levels: cardinal and inter-cardinal directions) and surveyed months (3 months: March, April and May). The interaction of the two factors was included in the model after computing the Akaike's information criterion (AIC) that allowed the selection of the model with best fit (i.e. lower AIC value) instead of ANOVA without interaction between factors. Moreover, multiple comparisons of means (Tukey HSD) were conducted to report which factor interactions were significantly different. The $\mathrm{R}$ Commander package $\{\mathrm{Rcmdr}\}$ in $\mathrm{R}$ was used was used in analyses.

\section{Results}

\section{Population dynamics}

Overall, population size of both surveyed species increased significantly over the 19 surveyed years in the park of ENSA. The curvilinear regression obtained with the four-parameter logistic function 'SSfpl' revealed that the population size of both species started of very low levels or zero in 1992, but it reached high densities particularly from 2002-2010 (Fig. 2). Before the latter period, the increase in population densities was insignificant in both species (non-significant asymptotes for low value 'parameter $A$ ' at first study years: $C$. palumbus: $t=2.07, d f=15, P=0.056$; $S$. decaocto: $t=-0.06$, $d f=15, P=0.950$ ) (Table 1). Indeed, the Eurasian Collared Dove has been newly established in the study area in 2002, so it proliferated progressively its individual numbers after that period. However, the two species indicated an asymptote for late years of the survey meaning that they reached their stabilisation during the period 2004-2010 for C. palumbus and 2007-2010 for $S$. decaocto (Fig. 2) with significant asymptotes at last years of the study (C. palumbus: $t=35.07, d f=15, P<0.001$; S. decaocto: $t=47.04, d f=15, P<0.001$ ) (Table 1). The parameters of the logistic model explaining the curve of population dynamics ( $N$ : number of pairs) through years $(Y r)$ could be written as: $N=3.156+((54.622-3.156) /$ $(1+\exp ((2001.1-Y r) / 0.872)))$ for the Woodpigeon, and $N=-0.026+((32.678+0.026) /$ $(1+\exp ((2003.8-Y r) / 1.067)))$ for the Eurasian Collared Dove.

\section{Woodpigeon (Columba palumbus)}

Two decades ago, the Woodpigeon was absent in urban areas of Algiers, except in few large parks and gardens. From 1992 to 2010, its numbers in the park of ENSA increased in the late 1990 s to reach about twenty pairs in 2000 and 2001 then reach high numbers (57 pairs/10 ha) in 2008 (Fig. 2). A similar trend has occurred throughout

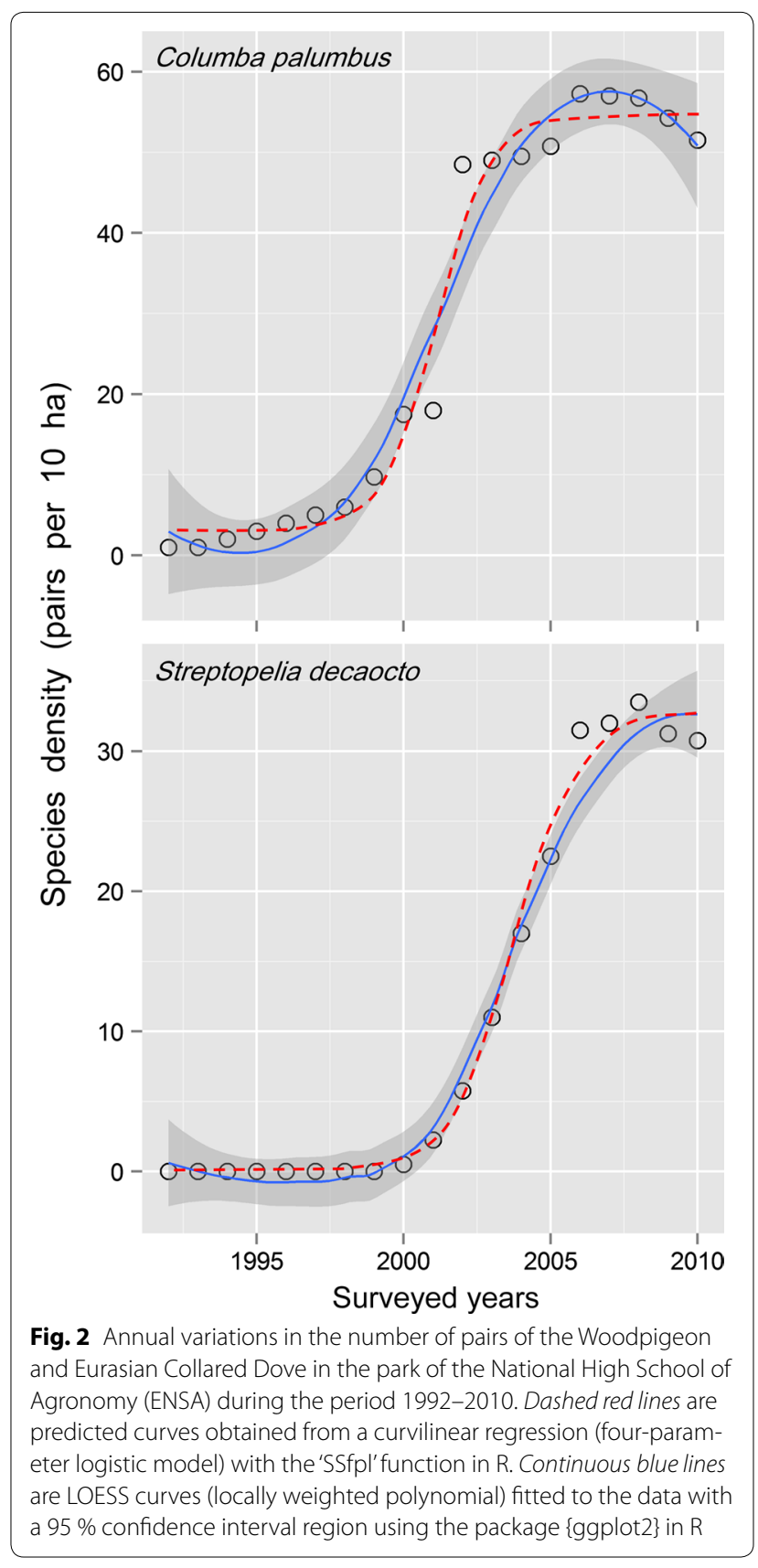

the Mitidja Plain, where since 2002 large flocks became regular (Fig. 3). For example in March 2006 near Baraki, flocks with up to 201 individuals were repetitively counted.

The Woodpigeon was observed foraging on the wide variety of vegetal food. During our surveys, the species was spotted eating cereals including Barley crop (Hordeum vulgare) and Maize (Zea mays). In addition, its diet also included Durum Wheat seeds (Triticum durum), Fig 
Table 1 Summary of models and parameterizations of four-parameter logistic S-shaped functions analyzing changes in annual population dynamics of study bird species

\begin{tabular}{llllr}
\hline Parameters & Estimate & Std. error & t-value & \multicolumn{1}{c}{$\boldsymbol{P}$} \\
\hline Woodpigeon & AIC $=110.67)$ & & & \\
A & 3.156 & 1.524 & 2.07 & 0.056 \\
B & 54.622 & 1.558 & 35.07 & $<0.001$ \\
C & 2001.1 & 0.201 & 9949.7 & $<0.001$ \\
D & 0.872 & 0.175 & 4.97 & $<0.001$ \\
Eurasian Collared Dove (AIC $=65.13)$ & & \\
A & -0.026 & 0.404 & -0.06 & 0.950 \\
B & 32.678 & 0.695 & 47.04 & $<0.001$ \\
C & 2003.8 & 0.116 & $17,247.5$ & $<0.001$ \\
D & 1.067 & 0.101 & 10.53 & $<0.001$ \\
\hline
\end{tabular}

AIC Akaike's information criterion; $A, B, C, D$ parameters the four-parameter logistic S-shaped function

(Ficus carica), accompanied by bulbils of Oxalis (Oxalis pescapre), Beans (Vicia sativa and V. faba), and Clover seeds (Trifolium angustifolium). Furthermore, it was possible to observe woodpigeon flocks of dozens individuals, throughout the Mitidja Plain, feeding on the young leaves of Narrow-leaved Ash (Fraxinus angustifolia) in MarchApril, or they unripe green acorns of Portuguese Oak (Quercus faginea) and Zeen Oak (Quercus canariensis) in September-October.
The species is now very common throughout the Plain of Mitidja and bordering regions, where it nests on garden trees, even those located near buildings where it frequents roofs. Moreover, large flying flocks of Woodpigeons, often exceeding 100 individuals, were observed throughout Algiers region (Fig. 3) in the late afternoon and until dusk, are the result of birds joining their roosts and that coming from their foraging sites, which are often situated far away in fields and orchards or in scrublands of northern Tellian Atlas.

Flights of woodpigeons surveyed in Mitidja mainly head to the south, southwest and to a lesser extent to the southeast in the morning (and back the other way to the roosts in the evening), but practically none eastward or westward (Figs. 3, 4). Woodpigeon flock densities varied significantly $(P<0.001)$ according to flight directions and study months as well as by their interaction (Table 2). This particular scheme of flying routes is due to the intense urbanization in sites of east region of Algiers, where woodpigeons certainly avoid the noisy animation and heavy traffic of people and vehicles. In addition, the west area of Algiers is an area of rugged hills, very dry and little favourable for woodpigeons because of the great scarcity of food resources. The significant variation of flight directions over time is due to different uses of foraging habitats as the productivity of these habitats also changes over time. This may be related to the change in nutritional needs following phenological breeding stages,

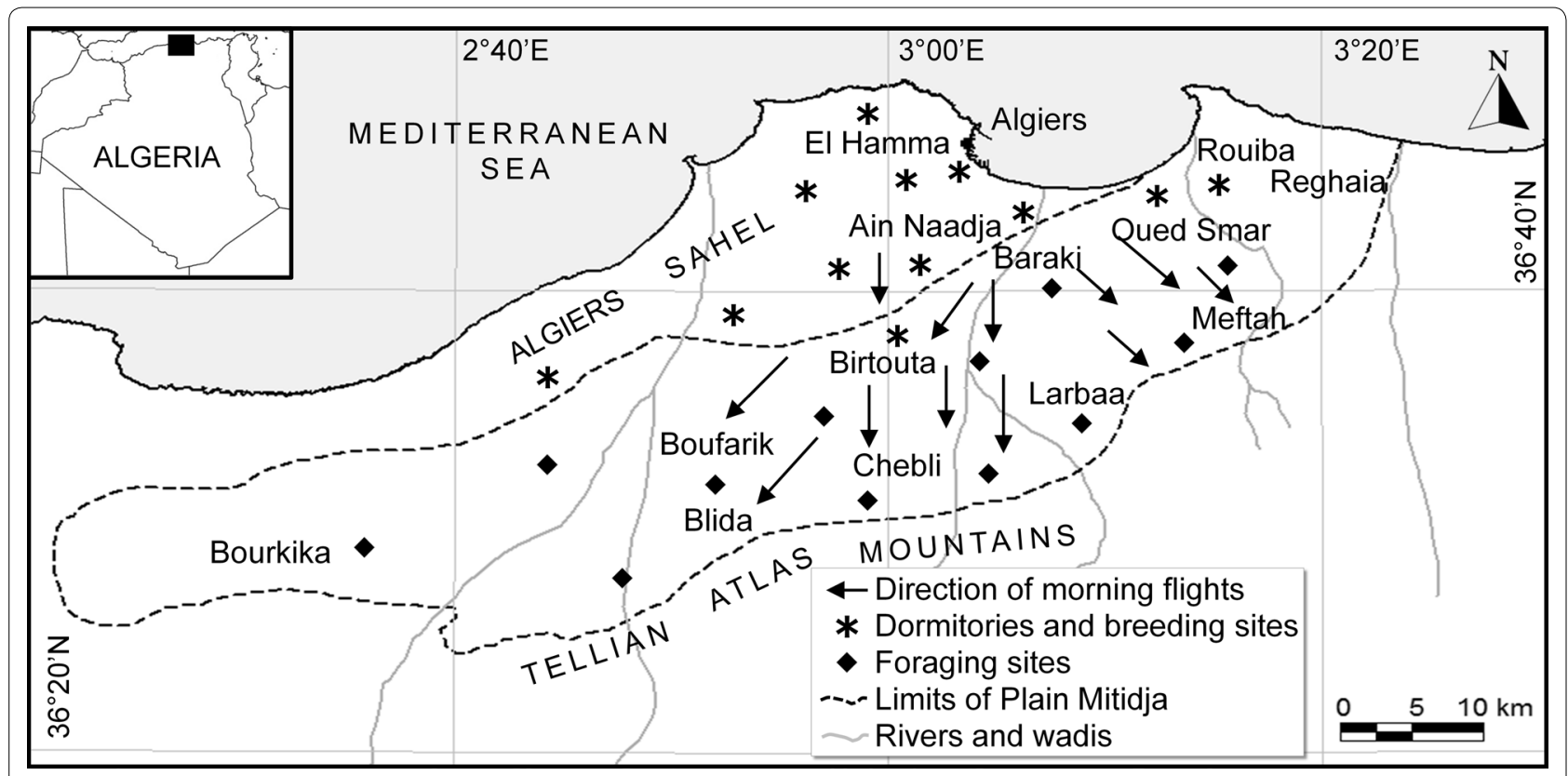

Fig. 3 Morning feeding flight routes of woodpigeons from parks and gardens of Algiers city to the foraging sites of the Mitidja Plain 


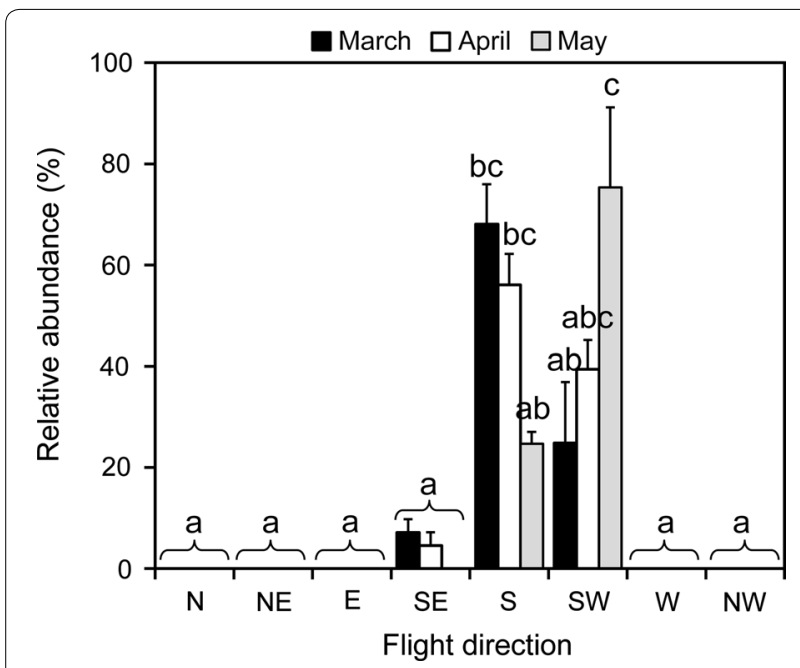

Fig. 4 Abundances of Woodpigeon numbers according to cardinal flight directions during March-May 2006 in Baraki station (Algiers). Vertical error bars represent standard deviations. Annual densities with the same letter are not significantly different $(P=0.05)$ following Tukey's HSD tests

Table 2 Two-way ANOVA testing variation of Woodpigeon's densities according to flight directions, study months and their interaction $(\mathrm{AIC}=450.4)$ in north Algeria

\begin{tabular}{lrrrrr}
\hline Variation sources & DF & \multicolumn{1}{c}{ SS } & MS & \multicolumn{1}{l}{$\boldsymbol{F}$} & $\boldsymbol{P}$ \\
\hline Flight directions & 7 & 11900.8 & 1700.1 & 10.9 & $<0.001$ \\
Study months & 2 & 3165.1 & 1582.5 & 10.2 & $<0.001$ \\
Interaction & 14 & 11851.6 & 846.5 & 5.4 & $<0.001$ \\
Residual error & 48 & 7458.0 & 155.4 & & \\
Total & 71 & 34375.5 & 484.2 & & \\
\hline
\end{tabular}

The same model without the interaction of two factors revealed an AIC $=461.6$

so the species change flight directions towards foraging habitats that match its feeding requirements [26].

\section{Eurasian Collared Dove (Streptopelia decaocto)}

In the park of ENSA, the first pair was observed in 2001, but after 2002, the increase of the species became extremely rapid as similar as numbers of Woodpigeon (Fig. 2). The occupancy of Algiers region by the Eurasian Collared Dove is still incomplete, wherein the species is confined in suburban environments close to dwellings. It is still absent in some areas/habitats and even within cities like Boufarik, Birtouta or Blida (Fig. 5). However, it began uses there some isolated farms from January 2006. Generally, it progresses in small steps of few kilometres per year, avoiding unpopulated areas, and taking advantage of farm buildings such as farmers' homes, barns of agricultural machinery, livestock housing and/or product storage structures. The species has not been met yet in groves and agricultural fields.

\section{Discussion}

This bird survey showed that the Woodpigeon, originally a forest bird species, is currently pursuing in Algeria a similar trend that had made of it a bird adapted to suburban parks and gardens of large cities in most European countries. In some cases, this observation is old; for example, it dates at least of the eighteenth century in Paris [27-29]. However, outside the cities, the Woodpigeon still has non-synanthropic behaviour and does not occur on farmland except if there is no disturbance source or any danger in sight.

The increase of Woodpigeon numbers in Algiers region seems to be related to an adaptation and change in species diet. Before 1990, the species fed mainly in forests of Mitidja Atlas mountains, where they found abundance food resources, including berries of Phillyrea angustifolia in July-August, Bay Noble (Laurus nobilis) in August-September, Zeen Oak acorns in October, and fruits of Olive (Olea europaea) in November-January [16]. Since 1990, repeated violent forest fires occurred annually in the region as in the rest of Algeria [30], which have significantly reduced food resources of the species. Deprived of very large part of its usual food, the Woodpigeon has to rely on farmland resources, which the species used already in the past with small flocks mainly coming from Tellian Atlas forests for foraging in the countryside around Algiers [31]. This decline in forest food resources has thus merely precipitated a process already well underway.

The food of Woodpigeon in Algiers plains is quite diverse. Our observations are quite similar to those reported in diet analysis of the species (e.g. [32]. Moreover, according to Merabet et al. [33], in early spring woodpigeons consume young leaves of ash trees that grow along Wadis of El Harrach, Boudouaou, and Hamiz; where it also ingests Loquat fruits (Eriobotrya japonica), young leaves of White Mulberry (Morus alba) and Elm (Ulmus campestris). In summer, Woodpigeons feed on green pods of Kurrajongs (Brachychiton populneum), Beans (Bauhinia purpurea), Figs and fruit of Mediterranean Hackberry (Celtis australis). In winter, they also eat dates of the Canary Palm (Phoenix canariensis), olives (Olea europaea), berries of Mediterranean Buckthorn (Rhamnus alaternus) and Japanese Privet (Ligustrum japonicum).

In our study area, during cool and wet periods, pigeons fled to sleep in the canopy of pine trees, which provide good shelter against rain and wind. In Bejaia, the species occupied crowns of Aleppo Pine (Pinus halepensis) 


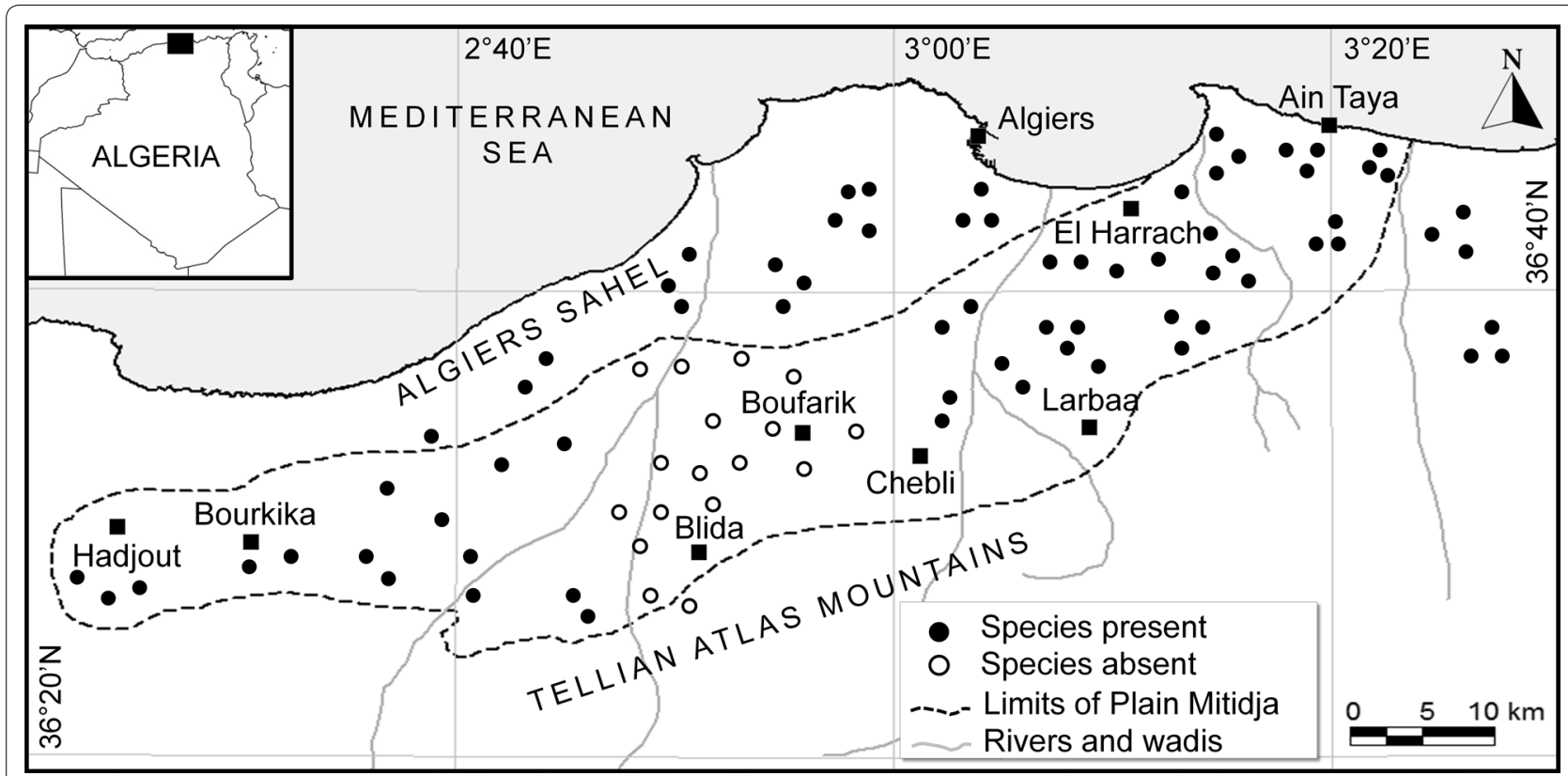

Fig. 5 Distribution of the Eurasian Collared Dove (Streptopelia decaocto) in the Mitidja Plain and the Sahel of Algiers (2004-2008)

located downtown, which are left in the morning to reach the Soummam Valley located at more than $10 \mathrm{~km}$ from the city [19]. During the period of nestling feeding (April-May), pigeons make flights of short range to the countryside around Algiers in order to supply their chicks.

Reasons of Woodpigeon's population increase in our study area during these nineteen years is based on the assumption that we are dealing with increasing sedentary populations; contrary to recruitments of few individual migrants reaching the area from northern Morocco and middle Europe during postnuptial migration [29, 34]. Moreover, we are uncertain if these migration routes may reach up central Algeria and thus lead to population increase. However, we hypothesize that the diminution in hunting pressure, reduced almost to zero, for over a decade in Algeria. Now, hunting is prohibited all times, except for some species such as wild boar (Sus scrofa). Generally, this factor was favourable for a wide range of game birds [35]. In addition, poaching of woodpigeons, although there is still, remains insignificant. Another high-probable hypothesis, but not exclusive as the one of hunting banning, is that the woodpigeons in Algiers region like in Europe, have developed adaptation to new and abundant food resources provided by the extensive agriculture. Indeed, woodpigeons still are predominantly occurring in natural woodland in Morocco, but they frequently forage in cultivated areas [27, 36-38]. In Europe, large cereal crop areas certainly played a key-role in increasing Woodpigeon populations [37, 39]. However, this factor seems insufficient to explain the same phenomenon in Algiers region, as cereals are intended for livestock feeding on one hand and they are seasonally produced and only on about 9300 ha (about $15 \%$ of all cropland areas) on the other hand. Under these conditions, even if the cereal production has favoured population growth of the Woodpigeon at its beginning, it will quickly become a limiting factor, if it is not already done so, unless the species is boarding its feeding niche by diversifying its diet and foraging on other plain habitats.

The first observation of the Eurasian Collared Dove in Algeria was carried out in a residential area of Annaba city in East Algeria, where 40 individuals were observed in March 1994 and then 115 individuals in December 1997 [17]. Later in 1999, the species was reported in Bejaia (Further west of Annaba) [40]. Its spread over the northern Algeria seems to have been slow because it took until March 2000 for the observation of first individual in coastal areas of Algiers [3].

Contrary, the establishment of the Eurasian Collared Dove in Tunisia is certainly old, because a small breeding population existed in 1963-1967 in Thibar [41]. It would probably be the same in Morocco, where it was considered as common in most cities particularly in coastal zones [34, 42]. These facts suggest that the Collared Dove dispersed towards Algiers area from the western or eastern extremity of the Maghreb, and most probably from the east, because no study reported its presence in western Algeria until 2001 [19]. In the Sahara Desert (South Algeria), it was reported in 2003 in Biskra [43] and in 
2007 in Tamanrasset [18]. Now, it is considered among the common bird species in several arid regions in Algeria $[44,45]$. These statements are naturally comparable with the well-known worldwide expansion patterns of the species, which has now colonized most of Europe and America, where its numbers are still growing even in areas where it had existed long time ago [46-48].

Well adapted to local conditions, the Eurasian Collared Dove sings and courtship displays anytime during the year, even out the breeding season and even more during rainy and snowy times, as was the case in late January 2005. It breeds from March and continues until mid-July, but in autumn (October-November), it is just displaying [49]. In this respect, its behaviour in Algeria is not different from that of populations living in Europe [34].

The fragmentation of lands and habitats of the Mitidja Plain and its surroundings into small areas with expansion of urbanization has indirectly led rapid expansion of the Eurasian Collared Dove and Woodpigeon. Factors that currently control numbers of these Columbidae species are predation, disturbance due to human activities and food availability, which has changed little in the past two decades. One of the main factors behind the current increase in numbers of Columbidae in Algiers region is the reduction of hunting pressure since 1990s, which has mainly benefited the Woodpigeon and the Eurasian collared dove. Adaptation to urban areas and the acclimatization to new food sources, for both surveyed species, have contributed to the increase of their numbers that was very clear in the Woodpigeon. In lights of these conditions, we are expecting further increases in both range and densities of species we surveyed. Therefore, further monitoring of such opportunistic species with large ecological valence is of key importance to understand the environment status and to assess possible ramifications for native avifauna.

\section{Authors' contributions}

$\mathrm{DB}$ and $\mathrm{SD}$ conceived and designed the research. DB, AM and NBB conducted the field work. HC analysed data. DB, HC and JFV interpreted results. $\mathrm{HC}$ and DB wrote the manuscript. All authors read and approved the manuscript.

\footnotetext{
Author details

${ }^{1}$ Department of Biology of Populations and Organisms, Faculty of Natural and Life Sciences, University of Blida 1, 09000 Blida, Algeria. ${ }^{2}$ Muséum National d'Histoire Naturelle, Entomologie, 57 rue Cuvier, C.P. 50, 75005 Paris, France. ${ }^{3}$ Department of Agricultural and Forestry Zoology, National Superior School of Agronomy (ENSA)-El Harrach, 16200 Algiers, Algeria. ${ }^{4}$ Department of Biology, Faculty of Sciences, University of M'Hamed Bougara, 35000 Boumerdes, Algeria. ${ }^{5}$ Department of Natural and Life Sciences, Faculty of Exact Sciences and Natural and Life Sciences, University of Tebessa, 12002 Tebessa, Algeria.

${ }^{6}$ Department of Natural and Life Sciences, Faculty of Sciences, University of E Hadj Lakhdar, 05000 Batna, Algeria.
}

\section{Acknowledgements}

We acknowledge the Director of ENSA for facilitating bird monitoring of Columbidae species within the ENSA Park. We are grateful to all rural residents and farm owners in Sidi Moussa, Meftah, Chebli, Ramadhnia, Bourkika, Birtouta, Boufarik, Bouinane, and Rouiba for helping the monitoring of the
Eurasian Collared Dove. We thank the Family Aliayachi owner of Baraki Farm (Algiers) for kindly letting us work on their properties while surveying foraging flights of the Woodpigeon. Thanks to Omar Guezoul and Adel Hamani for their valuable help with the fieldwork. This study comes within the framework of Franco-Algerian cooperation program "Tassili" No. 08MDU726. The author HC gratefully thanks Prof. Ken Norris (Institute of Zoology, Zoological Society of London, UK) for offering a hand copy of the book "The R Book. Second Edition" that was used in statistical modelling of data.

\section{Compliance with ethical guidelines}

\section{Competing interests}

The authors declare that they have no competing interests.

Received: 2 November 2014 Revised: 17 July 2015

Accepted: 11 September 2015

Published online: 23 September 2015

\section{References}

1. Marsh DM, Trenham PC. Current trends in plant and animal population monitoring. Conserv Biol. 2008;22:647-55.

2. Edman T, Angelstam P, Mikusinski G, Roberge JM, Sikora A. Spatial planning for biodiversity conservation: assessment of forest landscapes' conservation value using umbrella species requirements in Poland. Landscape Urban Plan. 2011;102:16-23.

3. Bendjoudi D, Chenchouni H, Doumandji S, Voisin J-F. Bird diversity in Plain Mitidja (North Algeria) with emphasis on dynamics of invasive and expanding species. Acrocephalus. 2013;34:13-26.

4. Huxel GR. Rapid displacement of native species by invasive species: effects of hybridization. Biol Conserv. 1999;89:143-52.

5. Pimentel D, Rodolfo Zuniga R, Morrison D. Update on the environmental and economic costs associated with alien-invasive species in the United States. Ecol Econ. 2005;52:273-88.

6. Strubbe D, Shwartz A, Chiron F. Concerns regarding the scientific evidence informing impact risk assessment and management recommendations for invasive birds. Biol Conserv. 2011;144:2112-8.

7. Cronk QCB, Fuller JL. Plant invaders: the threat to natural ecosystems. London: Chapman \& Hall; 1995.

8. Clavero M, Brotons B, Pons P, Sol D. Prominent role of invasive species in avian biodiversity loss. Biol Conserv. 2009;142:2043-9.

9. Dures SG, Cumming GS. The confounding influence of homogenising invasive species in a globally endangered and largely urban biome: does habitat quality dominate avian biodiversity? Biol Conserv. 2010;143:768-77.

10. Kumschick $S$, Nentwig W. Some alien birds have as severe an impact as the most effectual alien mammals in Europe. Biol Conserv. 2010;143:2757-62.

11. Van Rensburg BJ, Peacock DS, Robertson MP. Biotic homogenization and alien bird species along an urban gradient in South Africa. Landscape Urban Plan. 2009;92:233-41.

12. Anderies JM, Katti M, Shochat E. Living in the city: resource availability, predation, and bird population dynamics in urban areas. J Theor Biol. 2007;247:36-49.

13. Patón D, Romero F, Cuenca J, Escudero JC. Tolerance to noise in 91 bird species from 27 urban gardens of Iberian Peninsula. Landscape Urban Plan. 2012;104:1-8.

14. Reis E, López-lborra GM, Pinheiro RT. Changes in bird species richness through different levels of urbanization: implications for biodiversity conservation and garden design in Central Brazil. Landscape Urban Plan. 2012;107:31-42.

15. Møller AP. Successful city dwellers: a comparative study of the ecological characteristics of urban birds in the Western Palearctic. Oecologia. 2009;159:849-58.

16. Bendjoudi D. Etude de l'Avifaune de la Mitidja. PhD Thesis National Agronomical Institute, El Harrach; 2008.

17. Benyacoub S. La Tourterelle turque Streptopelia decaocto en Algérie. Alauda. 1998;66:251-3. 
18. Moali A, Isenmann P. La Tourterelle turque Streptopelia decaocto nicheuse en 2007 à Tamanrasset (Sahara central, Algérie) et son expansion au Sahara. Alauda. 2007;75:247-8

19. Moali A, Moali-Grine N, Fellous A, Isenmann P. Expansion spatiale de la Tourterelle turque Streptopelia decaocto et présence dans les parcs urbains du Pigeon ramier Columba palumbus en Algérie. Alauda. 2003;71:371-4.

20. Boukhemza-Zemmouri N, Belhamra M, Boukhemza M, Doumandji S, Voisin J-F. Biologie de reproduction de la Tourterelle des bois Streptopelia turtur arenicola dans le Nord de I'Algérie. Alauda. 2008;76:207-22.

21. Blondel J. Méthodes de dénombrement des populations d'oiseaux. In: Lamotte M, Bourliere F, editors. Problèmes d'Écologie: L'échantillonnage des Peuplements Animaux des Milieux Terrestres. Paris: Masson; 1969. p. 95-151.

22. Ochando B. Méthodes d'inventaires et de dénombrements d'oiseaux en milieu forestier. Application à I'Algérie. Annals of INA El Harrach 1988;12:47-59.

23. Paine CET, Marthews TR, Vogt DR, Purves D, Rees M, Hector A, Turnbull LA. How to fit nonlinear plant growth models and calculate growth rates: an update for ecologists. Methods Ecol Evol. 2012;3:245-56.

24. R Core Team. R: a language and environment for statistical computing R Foundation for Statistical Computing, Vienna, Austria. 2015. http:// www.R-project.org/.

25. Crawley MJ. The R book. 2nd ed. Chichester: Wiley; 2013. p. 715-39.

26. Chenchouni H, Si Bachir A, AlRashidi M. Trophic niche and feeding strategy of the White Stork (Ciconia ciconia) during different phases of the breeding season. Avian Biol Res. 2015;8:1-13.

27. Baptista LF, Trail PW, Morblit HM. Family Columbidae (Pigeons and Doves). In: Del Hoyo J, Elliott A, Sargatal A, editors. Handbook of the birds of the world, vol. 4. Barcelona: Lynx; 1997. p. 60-243

28. Saari L. Wood pigeon (Columba palumbus). In: Hagemeijer EJM, Blair MJ editors. The EBCC atlas of european breeding birds. Their Distribution and Abundance. London: T \& AD Poyser; 1997. p. 384-5.

29. Yeatman L. Atlas des Oiseaux Nicheurs de France de 1970 à 1975. Paris: Ministère de la Qualité de la Vie \& SEOF; 1976.

30. Meddour-Sahar O, Meddour R, Derridj A. Analyse des feux de forêts en Algérie sur le temps long (1876-2007). Les notes d'analyse du CIHEAM. 2008;39:10.

31. Heim De Balsac H, Mayaud N. Les oiseaux du Nord-Ouest de l'Afrique. Paris: Lechevalier; 1962.

32. Guezoul O, Doumandji S, Souttou K, Baziz B, Brahmi K. Première mention sur le comportement trophique des adultes du pigeon ramier Columba palumbus Linné, 1758 et du pigeon biset Columba livia Bonnaterre, 1790 dans un milieu sub-urbain près d'El Harrach. Ornithologia Algirica. 2004:4:11-6.

33. Merabet A, Bendjoudi D, Doumandji S, Baziz B. Place des columbiformes parmi les oiseaux de la Mitidja en milieux suburbains et agricoles: Emploi des E.F.P. International Conference on the Algerian Ornithology, 11-13 Nov 2006. Algeria: University of Batna; 2006.

34. Gibbs D, Barnes E, Cox J. Pigeons and Doves. The Banks: Pica Press; 2001.
35. Belhamra M. National Report on Hunting (Algeria). Building capacity for sustainable hunting of migratory birds in Mediterranean third countries. Project Ref: LIFE 04 TCY/INT/000054. 2005. http://www.birdlife.org/action/ change/sustainable_hunting/pdfs/shp_national_hunting_report_algeria. pdf.

36. Cherkaoui SI, Dakki M, Selmi S, Rguibi Idrissi H, Thevenot M. Les oiseaux de la Ma'Amora (Maroc): phénologie du peuplement, statut des espèces nicheuses et évolution depuis le début du vingtième siècle. Alauda. 2007:75:15-32.

37. Cramp S, Brooks DJ, Dunn E, Gillmor R, Hollom PAD, Hudson R, Nicholson EM, Ogilvie MA, Olney PJS, Roselaar CS, Simmons KEL, Voous KH, Wallace DIM, Wattel J, Wilson MG. Handbook of the birds of Europe, the Middle East and North Africa. The birds of the Western Palearctic (Terns to Woodpeckers), vol. IV. Oxford, New York: Oxford University Press; 1994.

38. Inglis IR, Isaacson AJ, Smith GC, Haynes PJ, Thearle RJP. The effect on the woodpigeon (Columba palumbus) of the introduction of oilseed rape into Britain. Agr Ecosyst Environ. 1997;61:113-21.

39. Julliard R, Jiguet F. Statut de conservation en 2003 des oiseaux communs nicheurs en France selon 15 ans de programme Stoc. Alauda. 2005;73:345-56.

40. Isenmann P, Moali A. Oiseaux d'Algérie-birds of Algeria. Paris: SEOF \& MNHN; 2000 .

41. Isenmann P, Gaultier Th, El Hilli A, Azafzaf H, Dlensi H, Smart M. Oiseaux de Tunisie-birds of Tunisia. Paris: SEOF \& MNHN; 2005.

42. Bergier P, Franchimont J, Thévenot M. Implantation et expansion géographique de deux espèces de Columbidés au Maroc: La Tourterelle turque Streptopelia decaocto et la Tourterelle maillée Streptopelia senegalensis. Alauda. 1999;67:23-36.

43. Guezoul O, Doumandji S, Voisin JF, Baziz B, Souttou K, Sekour M. Contribution à l'Ornithologie dans deux régions phénicicoles (Sahara septentrional). In: International Conference Algerian Ornithology, 11-13 Nov 2006. Algeria: University of Batna; 2006.

44. Chenchouni H. Diversity assessment of vertebrate fauna in a wetland of hot hyperarid lands. Arid Ecosystems. 2012;2:253-63.

45. Guezoul O, Chenchouni H, Sekour M, Ababsa L, Souttou K, Doumandji S. An avifaunal survey of mesic manmade ecosystems "Oases" in Algerian hot-hyperarid lands. Saudi J Biol Sci. 2013;20:37-43.

46. Eraud C, Boutin J-M, Roux D, Faivre B. Spatial dynamics of an invasive bird species assessed using robust design occupancy analysis: the case of the Eurasian collared dove (Streptopelia decaocto) in France. J Biogeogr. 2007;34:1077-86.

47. Fujisaki I, Pearlstine EV, Mazzotti FJ. The rapid spread of invasive Eurasian Collared Doves Streptopelia decaocto in the continental USA follows human-altered habitats. Ibis. 2010;152:622-32.

48. Hengeveld R, Van Den Bosch F. The expansion velocity of the Collared Dove (Streptopelia decaocto) population in Europe. Ardea. 1991;79:67-72.

49. Bendjoudi D. Le peuplement avien de la Mitidja du nouveau en particulier sur les espèces introduites ou en plein extension. In: The 3rd International Seminar on Animal Biology, 09-11 May 2011. Algeria: University of Constantine; 2011.

\section{Submit your next manuscript to BioMed Central and take full advantage of:}

- Convenient online submission

- Thorough peer review

- No space constraints or color figure charges

- Immediate publication on acceptance

- Inclusion in PubMed, CAS, Scopus and Google Scholar

- Research which is freely available for redistribution

Submit your manuscript at 